\title{
52. DATA REPORT: EXTRACTABLE HYDROCARBON AND CARBON ISOTOPE GEOCHEMISTRY OF LOWER CRETACEOUS SEDIMENTS FROM SITES 762 AND 763 ON THE EXMOUTH PLATEAU, NORTHWEST AUSTRALIAN MARGIN ${ }^{1}$
}

\author{
Philip A. Meyers ${ }^{2}$ and Lloyd R. Snowdon ${ }^{3}$
}

\begin{abstract}
The organic geochemical character of rocks selected from Aptian, Valanginian, and Berriasian claystone and siltstone sequences encountered in Ocean Drilling Program (ODP) Holes $762 \mathrm{C}$ and $763 \mathrm{C}$ on the Exmouth Plateau was determined by means of a variety of analytical procedures. These sequences represent distal portions of the Mesozoic Barrow delta, in which petroleum source rocks and reservoirs exist on the Australian continent. The organic matter at the ODP sites is thermally immature type III material. Biomarker hydrocarbon compositions are dominated by long-chain, waxy $n$-alkanes and by $\mathrm{C}_{29}$ steranes, which reflect the land-plant origin of organic matter. Organic carbon $\delta^{13} \mathrm{C}$ values ranged from $-26 \%$ to $-28 \%$, consistent with a $\mathrm{C} 3$ land-plant source. Kerogen pyrolysate compositions and hopane isomerization ratios revealed progressively larger contributions of recycled organic matter as the depth of the deltaic sedimentary layers became greater.
\end{abstract}

\section{INTRODUCTION}

The Exmouth ${ }^{1}$ Plateau ${ }^{2}$ on $^{3}$ the northwestern Australian continental margin consists of rifted and deeply subsided continental crust isolated from the Australian shelf by the Kangaroo Syncline (Exon et al., 1982). Before Jurassic rifting, clastic sediments reaching $10 \mathrm{~km}$ in thickness were deposited as part of the Barrow Delta Formation. These rocks typically contain $1 \%-2 \%$ organic carbon, mostly derived from land plants (Barber, 1982; Campbell et al., 1984; Cook et al., 1985). After tectonic isolation from Australia during the Early Cretaceous, a limited amount of terrigenous sediment accumulated, and the biogenous sediments that were deposited since then contain very small amounts of organic matter (cf. Snowdon and Meyers, this volume). The deeper sections of this deltaic sedimentary sequence generated oil and gas and are the source of commercial production on the Australian shelf and farther inland.

Sites 762 and 763 on the Exmouth Plateau (Fig. 1) were selected to investigate the postrift geology of this feature. Drilling at both sites was limited to the uppermost portions of the Barrow Delta to avoid penetrating suspected petroleum reservoirs in the deeper portions. The thicknesses of the different phases of the deltaic sedimentation vary between the two sites, but combination of the two sections provides a composite history of the final events in the accumulation of terrigenous sediments on this feature of the northwest Australian margin. As a contribution to the depositional history, organic matter was characterized from sediments deposited at different phases of Late Cretaceous terrigenous accumulation.

\footnotetext{
${ }^{1}$ von Rad, U., Haq, B. U., et al., 1992. Proc. ODP, Sci. Results, 122: College Station, TX (Ocean Drilling Program).

2 Department of Geological Sciences, The University of Michigan, Ann Arbor, MI 48109-1063, U.S.A.

${ }^{3}$ Institute of Sedimentary and Petroleum Geology, Geological Survey of Canada, Calgary T2L 2A7, Canada.
}

\section{SAMPLING AND ANALYSIS}

\section{Samples}

Samples of sediment remaining after pore waters had been squeezed from them were selected for study of their organic matter contents. This procedure was chosen because fairly large amounts of sediment could be obtained and because additional information about the inorganic compositions of the sediments would ultimately become available. A total of five samples were collected. They include one from the equivalent of the onshore Aptian Muderong Formation, three from the equivalent of the Valanginian Barrow Group B, and one from the equivalent of the Berriasian Barrow Group C.

\section{Analysis}

Extractions and preliminary analyses of the samples were made onboard the JOIDES Resolution. The freeze-dried samples were extracted with chloroform/methanol (80/20) either by refluxing for $12 \mathrm{hr}$ or by using ultrasound for $15 \mathrm{~min}$. Solvents were evaporated from the extracted material, and the dried residue was redissolved in hexane for transfer to a silica gel chromatography column. The saturated hydrocarbon fraction was eluted from the column in hexane and analyzed by capillary gas chromatography, first onboard the ship and later on shore.

Two gas chromatographs were used. The shipboard instrument was a Hewlett Packard 5890 FID instrument equipped with a split/splitless injection port, and the shore-based one was a Varian 3700 FID gas chromatograph fitted with an splitter injection port and a 30-m DB-1 fused silica column. Silica gel column chromatography of the extracts was repeated in the shore-based laboratory. In addition, combined gas chromatography-mass spectrometry (GC-MS) was done onshore using a Kratos MS-80 mass spectrometer interfaced with a Carlo Erba gas chromatograph and a DS-90 data system.

Total organic carbon (TOC) concentrations were determined onboard the JOIDES Resolution as part of Rock-Eval analyses of samples with a Girdel Rock-Eval II instrumentequipped with a TOC module. Samples were pyrolyzed by heating at a rate of $25^{\circ} \mathrm{C} / \mathrm{min}$ from $300^{\circ}$ to $600^{\circ} \mathrm{C}$, yielding the amounts of preformed hydrocarbons $\left(\mathrm{S}_{1}\right)$, thermogenic hydrocarbons $\left(\mathrm{S}_{2}\right)$, and $\mathrm{CO}_{2}$ released during pyrolysis to $390^{\circ} \mathrm{C}\left(\mathrm{S}_{3}\right)$. The TOC module combusts the residue of the temperature- 


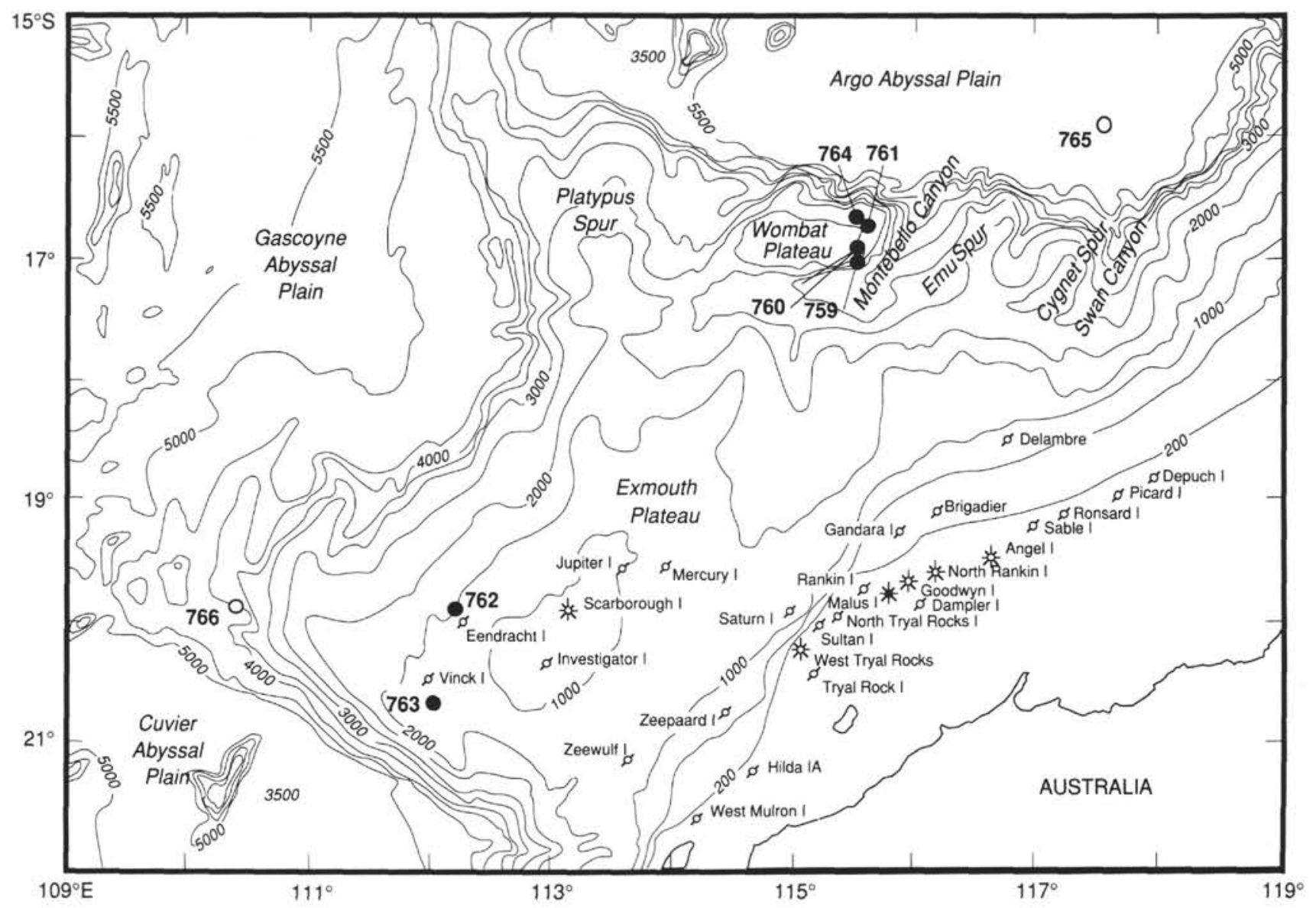

Figure 1. Locations of Sites 762 and 763 on the Exmouth Plateau, northwest Australian margin. Positions of exploratory wells are shown. Water depths given in meters.

programmed sample in air at $600^{\circ} \mathrm{C}$ and algorithmically determines the carbon content of this oxidation peak as well as the carbon in the pyrolysis peaks to give the TOC. These values provide the information to calculate the hydrogen index $(\mathrm{HI}=$ $\left.100 \times \mathrm{S}_{2} / \mathrm{TOC}\right)$ and the oxygen index $\left(\mathrm{OI}=100 \times \mathrm{S}_{3} / \mathrm{TOC}\right)$. The temperature of maximum hydrocarbon release during pyrolysis $\left(\mathrm{T}_{\max }\right)$ was also obtained and interpreted as a measure of organic matter thermal maturity (cf. Espitalié et al., 1977).

Concentrations of calcium carbonate were estimated using the carbonate bomb technique of Müller and Gastner (1971), which measures the amount of $\mathrm{CO}_{2}$ liberated by acidifying the samples. The $\mathrm{CO}_{2}$ values were used to calculate the carbonate contents of our samples, assuming that calcite was the only carbonate mineral present.

Carbon and oxygen isotope measurements were taken in the Light Stable Isotope Laboratory at The University of Michigan. Stable oxygen and carbon isotope ratios of carbonate minerals were determined by acidifying the samples and measuring the ${ }^{18} \mathrm{O} /{ }^{16} \mathrm{O}$ and ${ }^{13} \mathrm{C} /{ }^{12} \mathrm{C}$ ratios by means of a Finnegan MAT Model 251 mass spectrometer equipped with an automated analysis system. The ${ }^{13} \mathrm{C} /{ }^{12} \mathrm{C}$ ratios of organic carbon were measured with a Finnegan Delta $\mathrm{S}$ mass spectrometer after oxidizing the carbonate-free samples. National Bureau of Standards carbon isotope standards were routinely and frequently used to calibrate the instruments. Results are reported relative to the PDB standard.

Four of the samples were examined by the Pyran pyroanalytical system after biomarker extraction. In this sophisticated procedure, developed by Ruska Laboratories in Houston, a thermal chromatograph-mass spectrometer breaks down organic matter over a carefully controlled temperature range and then analyzes the molecular fragments released. Pyrolysis was achieved by heating samples from $330^{\circ}$ to $600^{\circ} \mathrm{C}$ at $30^{\circ} \mathrm{C} / \mathrm{min}$, and a total pyrolysate yield over this temperature range was produced. The total yield was then separated into component biomarker fragments by capillary gas chromatography-mass spectrometry. The capillary column employed in this study was a $30-\mathrm{m} \times 0.25-\mathrm{mm}$ DB- 5 column operated over a temperature range from $-35^{\circ}$ to $315^{\circ} \mathrm{C}$ at a heating rate of $5^{\circ} \mathrm{C} / \mathrm{min}$.

Extractable biomarkers typically constitute a very small, albeit significant, fraction of the total organic matter. For this reason, it is informative to examine the geochemical composition of bulk organic matter in samples for which the biomarker contents have been extracted and identified. The Pyran procedure was used to isolate and identify biomarker compounds incorporated into the nonextractable kerogen matrix of the Mesozoic rocks from the Exmouth Plateau.

\section{RESULTS AND DISCUSSION}

The results of the shipboard analyses of the hydrocarbon extractions are discussed in the site summary chapters for Sites 762 and 763 (Haq, von Rad, O'Connell, et al., 1990). These discussions note the presence of important contributions of land-derived, long-carbon-chain $n$-alkanes in the distribution of extractable hydrocarbons, but the general dominance of shorter chain algal $n$-alkanes. They also note a discrepancy between the marine-dominated character of the extracts and the overall land-derived nature, as indicated by 
Rock-Eval results, of the organic matter contents of the Lower Cretaceous sequences of Sites 762 and 763.

Chromatograms from the shore-based analyses of the saturated hydrocarbon contents extracted from the five Lower Cretaceous samples we examined show that long-chain $n$-alkanes diagnostic of the epicuticular waxes of higher land plants are dominant (Fig. 2). This dominance is particularly evident in the four samples from Exmouth Plateau sequences equivalent to parts of the Neocomian Barrow Formation in northwest Australia. In Sample 122-763B-45X-3, 140-150 cm, the contributions of marine and terrigenous $n$-alkane biomarkers are equivalent; this Aptian claystone corresponds to the Muderong Formation onshore.

The results of shipboard and shore-based chromatographic analyses are not the same, although shore-based repetition of the shipboard silica gel chromatographic separation verified that the initial separation was adequate and was not the cause of the difference. A comparison of the ratios of selected components of the saturated hydrocarbon distributions (Table 1) confirms the visual impression given by the chromatograms that the most significant difference between the two analyses resides in the relative proportions of long- and short-chain components. This ratio, comprised of the sum of $\mathrm{C}_{27}+\mathrm{C}_{29}+$ $\mathrm{C}_{31}$ divided by the sum of $\mathrm{C}_{17}+\mathrm{C}_{19}+\mathrm{C}_{21}$, is between 3 and 8 times larger in the land-based chromatograms than in the shipboard ones described in the site summary chapters (Haq, von Rad, O'Connell, et al., 1990). Similarly, the odd/even ratio is systematically higher for the shore-based data, a difference that reflects the high odd-carbon-number predominance of the $\mathrm{C}_{25}$ fraction, a minor component of the shipboard chromatograms. In contrast, the ratios of the closely eluting pristane/phytane, pristane $/ n-\mathrm{C}_{17}$, and phytane $/ n-\mathrm{C}_{18}$ components from the two types of chromatograms are generally in good agreement.

Possible explanations for the discrepancy between hydrocarbon and Rock-Eval source character inferences were offered in the site summary chapters. These were that either the low thermal maturity of the organic matter was adequate to yield extractable hydrocarbons only from type I (algal) organic matter or that the shipboard gas chromatograph selectively discriminated against higher molecular-weight hydrocarbons. The land-based analyses resolve the discrepancy and show that the shipboard system did in fact discriminate against the terrigenous biomarker compounds. We speculate that the somewhat large dead volume of the split/splitless injection inlet was responsible for the proportionally larger losses of the less volatile long-chain $n$-alkanes.

Consistent with the low thermal maturity indicated by Rock-Eval $\mathrm{T}_{\max }$ values that ranged from $425^{\circ}$ to $435^{\circ} \mathrm{C}$ (Haq, von Rad, O'Connell, et al., 1990), the $n$-alkane odd/even ratios calculated from $n-\mathrm{C}_{16}$ to $n-\mathrm{C}_{33}$ are fairly high (Table 1). Values for Neocomian samples are actually higher than for the Aptian sample, averaging 1.92 as opposed to 1.32 in the shore-based data. This cannot be simply an effect of maturity and must include a source character change, inasmuch as the Berriasian sample has the highest odd/even ratio of the five samples. Inspection of the chromatograms (Fig. 2) shows that it is the land-derived, long-chain $n$-alkanes that have a strong odd/ even predominance. The shorter chain marine hydrocarbons, which comprise about half of the Aptian distribution, lack a strong odd/even character; these may include bacterial components, which typically have low odd/even signatures.

The pristane/phytane ratios are above one in all the samples, a common observation in clastic sedimentary rocks. This value also suggests that methanogenic bacteria have not been active in these sedimentary settings, inasmuch as such bacteria typically synthesize phytane precursor compounds, rather

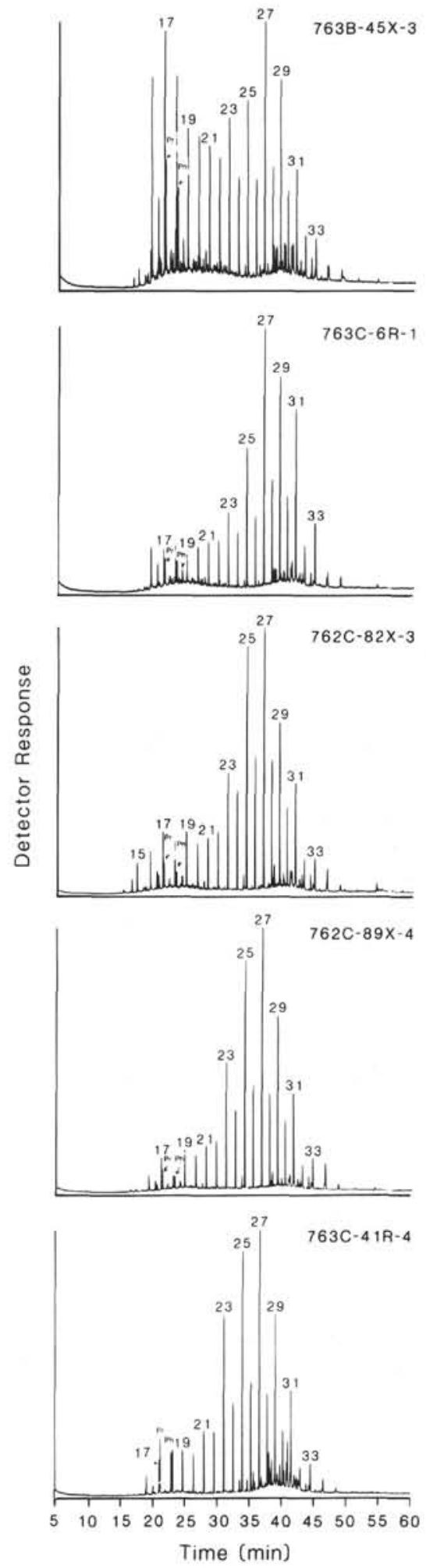

Figure 2. Chromatograms of extractable hydrocarbon fractions from Lower Cretaceous samples from Sites 762 and 763. Major $n$-alkanes are identified by their carbon numbers; the isoprenoid hydrocarbons pristane and phytane are identified by $\mathrm{pr}$ and $\mathrm{ph}$, respectively. Long-chain $n$-alkanes representative of land plant contributions dominate all of the chromatograms except for Sample 122-763B-45X-3 from the offshore equivalent of the Aptian Muderong Formation on Australia. Gas chromatographic details: Varian 3700 FID GC equipped with a $30-\mathrm{m}$ DB-1 capillary column. 
Table 1. Descriptions and extractable hydrocarbon characteristics of rock samples from selected Lower Cretaceous sequences in Holes 762C, 763B, and 763C, Exmouth Plateau.

\begin{tabular}{|c|c|c|c|c|c|c|c|c|c|c|}
\hline \multirow[b]{2}{*}{ Sample and description } & \multicolumn{2}{|c|}{ Long/short } & \multicolumn{2}{|c|}{ Odd/even } & \multicolumn{2}{|c|}{$\mathrm{Pr} / \mathrm{Ph}$} & \multicolumn{2}{|c|}{$\mathrm{Pr} / n-\mathrm{C}_{17}$} & \multicolumn{2}{|c|}{$\mathrm{Ph} / n-\mathrm{C}_{18}$} \\
\hline & Ship & Shore & Ship & Shore & Ship & Shore & Ship & Shore & Ship & Shore \\
\hline $\begin{array}{l}\text { 122-763B-45X-3, } 140-150 \mathrm{~cm} \\
\text { Aptian black silty claystone } \\
\text { (Muderong Formation equivalent) }\end{array}$ & 0.26 & 1.07 & 1.21 & 1.32 & 1.23 & 1.43 & 0.52 & 0.48 & 0.64 & 0.36 \\
\hline $\begin{array}{l}\text { 122-763C-6R-1, } 140-150 \mathrm{~cm} \\
\text { Valanginian dark gray silty claystone } \\
\text { (Barrow Group B equivalent) }\end{array}$ & 0.73 & 5.45 & 1.26 & 1.92 & 1.27 & 1.14 & 0.55 & 0.76 & 0.56 & 0.60 \\
\hline $\begin{array}{l}122-762 \mathrm{C}-82 \mathrm{X}-3,140-150 \mathrm{~cm} \\
\text { Valanginian dark gray silty claystone } \\
\text { (Barrow Group B equivalent) }\end{array}$ & 0.47 & 3.17 & 1.36 & 1.63 & 1.53 & 1.44 & 0.44 & 0.76 & 0.32 & 0.36 \\
\hline $\begin{array}{l}122-762 \mathrm{C}-89 \mathrm{X}-4,140-150 \mathrm{~cm} \\
\text { Valanginian dark gray silty claystone } \\
\text { (Barrow Group B equivalent) }\end{array}$ & 1.43 & 4.54 & 1.97 & 2.05 & 1.75 & 1.71 & 0.51 & 0.66 & 0.34 & 0.37 \\
\hline $\begin{array}{l}122-763 \mathrm{C}-41 \mathrm{R}-4,140-150 \mathrm{~cm} \\
\text { Berriasian dark gray clayey siltstone } \\
\text { (Barrow Group C equivalent) }\end{array}$ & 0.82 & 3.77 & 1.73 & 2.08 & 1.28 & 1.21 & 1.18 & 1.65 & 0.87 & 1.17 \\
\hline
\end{tabular}

Table 2. Sterane and triterpane compositions of extracts from Early Cretaceous rocks, Sites 762 and 763, Exmouth Plateau.

\begin{tabular}{|c|c|c|c|c|c|c|c|c|c|c|}
\hline \multirow[b]{2}{*}{ Sample } & \multirow[b]{2}{*}{ Age } & \multicolumn{4}{|c|}{ Sterane percentage } & \multicolumn{3}{|c|}{$\begin{array}{l}\text { Triterpane } \\
\text { percentage }\end{array}$} & \multicolumn{2}{|c|}{ Hopane ratios } \\
\hline & & 27 & 28 & 29 & 30 & 29 & 30 & 31 & $30 \beta \beta / \alpha \beta$ & $31 \beta \beta / \alpha \beta$ \\
\hline $\begin{array}{l}\text { 122-763B-45X-3, } 140-150 \mathrm{~cm} \\
\text { (Muderong Formation equivalent) }\end{array}$ & Aptian & 34 & 34 & 28 & 5 & 23 & 37 & 40 & 0.46 & 0.34 \\
\hline $\begin{array}{l}\text { 122-763C-6R-1, } 140-150 \mathrm{~cm} \\
\text { (Barrow Group B equivalent) }\end{array}$ & Valanginian & 36 & 12 & 44 & 7 & 21 & 39 & 40 & 0.72 & 0.75 \\
\hline $\begin{array}{l}\text { 122-762C-82X-3, } 140-150 \mathrm{~cm} \\
\text { (Barrow Group B equivalent) }\end{array}$ & Valanginian & 31 & 13 & 63 & 4 & 19 & 37 & 44 & 0.98 & 0.93 \\
\hline $\begin{array}{l}\text { 122-762C-89X-4, } 140-150 \mathrm{~cm} \\
\text { (Barrow Group B equivalent) }\end{array}$ & Valanginian & 28 & 11 & 56 & 5 & 11 & 44 & 46 & 1.11 & 1.31 \\
\hline $\begin{array}{l}\text { 122-763C-41R-4, } 140-150 \mathrm{~cm} \\
\text { (Barrow Group C equivalent) }\end{array}$ & Berriasian & 26 & 18 & 41 & 14 & 14 & 54 & 32 & 1.33 & 1.13 \\
\hline
\end{tabular}

Note: Expressed as percentages of total steranes or triterpanes.

Table 3. Descriptions and bulk organic matter characteristics of rock samples from selected Lower Cretaceous sequences in Holes 762C, 763B, and 763C, Exmouth Plateau.

\begin{tabular}{|c|c|c|c|c|c|c|c|c|}
\hline \multirow[b]{2}{*}{ Sample and description } & \multirow{2}{*}{$\begin{array}{l}\text { Depth } \\
\text { (mbsf) }\end{array}$} & \multirow{2}{*}{$\begin{array}{c}\mathrm{CaCO}_{3} \\
(\%)\end{array}$} & \multirow{2}{*}{$\begin{array}{l}\text { TOC } \\
(\%)\end{array}$} & \multicolumn{2}{|c|}{$\delta^{13} \mathrm{C}(\%)$} & \multicolumn{3}{|c|}{ Rock-Eval } \\
\hline & & & & Inorganic & Organic & HI & OI & $\mathrm{T}_{\max }$ \\
\hline $\begin{array}{l}\text { 122B-763B-45X-3, } 140-150 \mathrm{~cm} \\
\text { Aptian black silty claystone } \\
\text { (Muderong Formation equivalent) }\end{array}$ & 602.9 & 12.7 & 1.70 & -0.9 & -28.4 & 167 & 51 & $431^{\circ} \mathrm{C}$ \\
\hline $\begin{array}{l}122-763 \mathrm{C}-6 \mathrm{R}-1,140-150 \mathrm{~cm} \\
\text { Valanginian dark gray silty claystone } \\
\text { (Barrow Group B equivalent) }\end{array}$ & 662.0 & 12.4 & 0.89 & -8.0 & -28.3 & 144 & 46 & $424^{\circ} \mathrm{C}$ \\
\hline $\begin{array}{l}122-762 \mathrm{C}-82 \mathrm{X}-3,140-150 \mathrm{~cm} \\
\text { Valanginian dark gray silty claystone } \\
\text { (Barrow Group B equivalent) }\end{array}$ & 857.9 & 11.7 & 1.14 & -9.4 & -26.7 & 137 & 35 & $426^{\circ} \mathrm{C}$ \\
\hline $\begin{array}{l}122-762 \mathrm{C}-89 \mathrm{X}-4,140-150 \mathrm{~cm} \\
\text { Valanginian dark gray silty claystone } \\
\text { (Barrow Group B equivalent) }\end{array}$ & 916.5 & 14.2 & $\begin{array}{c}0.77^{*} \\
(0.15)\end{array}$ & -19.1 & -27.5 & $\begin{array}{c}96 * \\
(19)\end{array}$ & $\begin{array}{l}149^{*} \\
(53)\end{array}$ & $\begin{array}{c}424^{\circ} \mathrm{C}^{*} \\
\text { (7) }\end{array}$ \\
\hline $\begin{array}{l}\text { 122-763C-41R-4, } 140-150 \mathrm{~cm} \\
\text { Berriasian dark gray clayey siltstone } \\
\text { (Barrow Group C equivalent) }\end{array}$ & 985.5 & $\begin{array}{l}3.3^{*} \\
(0.9)\end{array}$ & $\begin{array}{c}0.98^{*} \\
(0.09)\end{array}$ & -0.4 & n.d. & $\begin{array}{l}178^{*} \\
(22)\end{array}$ & $\begin{array}{l}110^{*} \\
(23)\end{array}$ & $\begin{array}{c}433^{\circ} \mathrm{C}^{*} \\
\text { (2) }\end{array}$ \\
\hline
\end{tabular}

Notes: ${ }^{*}=$ not determined on this sample; the mean value of samples within $10 \mathrm{~m}$ has been substituted (SD). $\mathrm{HI}=$ hydrogen index, $\mathrm{OI}=$ oxygen index, and n.d. $=$ not determined. 
than precursors to pristane (Risatti et al., 1984). Diminished microbial activity is typical of settings in which the organic matter is dominated by detrital land-derived material, rather than more easily metabolized marine material. The two isoprenoid compounds make smaller contributions to the total hydrocarbons than the $n-\mathrm{C}_{17}$ and $n-\mathrm{C}_{18}$ components in all of the samples except Sample 122-763C-41R-4, 140-150 cm, equivalent to the Berriasian Group $C$ siltstone of the Barrow Formation. Marine contributions of extractable hydrocarbons may be smaller in this sample than in the others.

The compilations of sterane and pentacyclic triterpane distributions in Table 2 confirm the dominance of land-derived organic matter in the extracts of the Neocomian rocks and the subequal contributions of marine and terrigenous components in the Aptian sample. The low thermal maturity suggested by $n$-alkane odd/even ratios is verified by the total hopane $\beta \beta / \alpha \beta$ ratios. A progressive increase in these ratios as the age of the sediments increases is opposite to what would be shown by progressive thermal maturation of the extractable fraction of organic matter. The existence of this unexpected trend (Table 2) probably indicates progressively larger contributions of recycled organic matter in deeper layers of sediment deposited in this distal deltaic formation; it cannot be related to in situ thermal maturation effects.

Rock-Eval and $\delta^{13} \mathrm{C}$ data in Table 3 are consistent with a continental vegetation origin for most of the organic matter contained in these Cretaceous clastic rocks. Oxygen indexes are low, but most importantly the hydrogen indexes are also low, in the neighborhood of $150-\mathrm{mg}$ hydrocarbons $/ \mathrm{g}$ TOC. The organic carbon stable isotope ratios are uniformly typical of those of C3 land plants (ca. $-27 \%$ o). Inorganic carbon isotope values, in contrast, have a surprisingly broad range (essentially from $0 \%$ o to $-22 \%$ ). The light values are unexpected, inasmuch as most carbonates have ratios close to marine carbonate values (about $0 \%$ to $2 \%$ o). The isotopically light carbonate values may result from oxidation of organic carbon and incorporation of the $\mathrm{CO}_{2}$ so produced into carbonates. This type of organic-matter recycling is quite possible on the Exmouth Plateau, where large volumes of methane appear to have migrated through the Cretaceous sediments from deeper Jurassic sources (Snowdon and Meyers, this volume). A similar situation of methane oxidation and precipitation of isotopically light carbonate has been postulated in Miocene hemipelagic sediments at Sites 767 and 768 (von Breymann and Berner, 1990).

Pyrograms of the Aptian and Valanginian claystones are compared with a pyrogram of a modern lake sediment in Figure 3. The organic matter in the Early Cretaceous rocks pyrolyzes at a narrower and higher temperature range (ca. $450^{\circ} \mathrm{C}$ ) than the modern, mostly land-derived organic matter in the sample from Coburn Pond, Maine. The difference presumably results from the greater condensation of bulk organic matter into kerogen in the ancient sediments than in more modern ones. Some lower molecular weight fragments appear in the Aptian pyrogram at a pyrolysis time of $15 \mathrm{~min}$, corresponding to a temperature of $300^{\circ} \mathrm{C}$. As noted from the extractable biomarker distributions shown in Figure 2 and summarized in Table 1, this sample differs from the Valanginian samples in containing a larger proportion of marine components. Differences evidently exist in bulk kerogen as well, although these differences are not evident from $\delta^{13} \mathrm{C}$ values (Table 3 ).

The results of capillary gas chromatography-mass spectrometry of the pyrolysates show that a large proportion of cyclic molecules are produced from the kerogen of these Mesozoic sediments. Continental plant matter, rich in cellulose and lignin, would yield such fragments on pyrolysis.

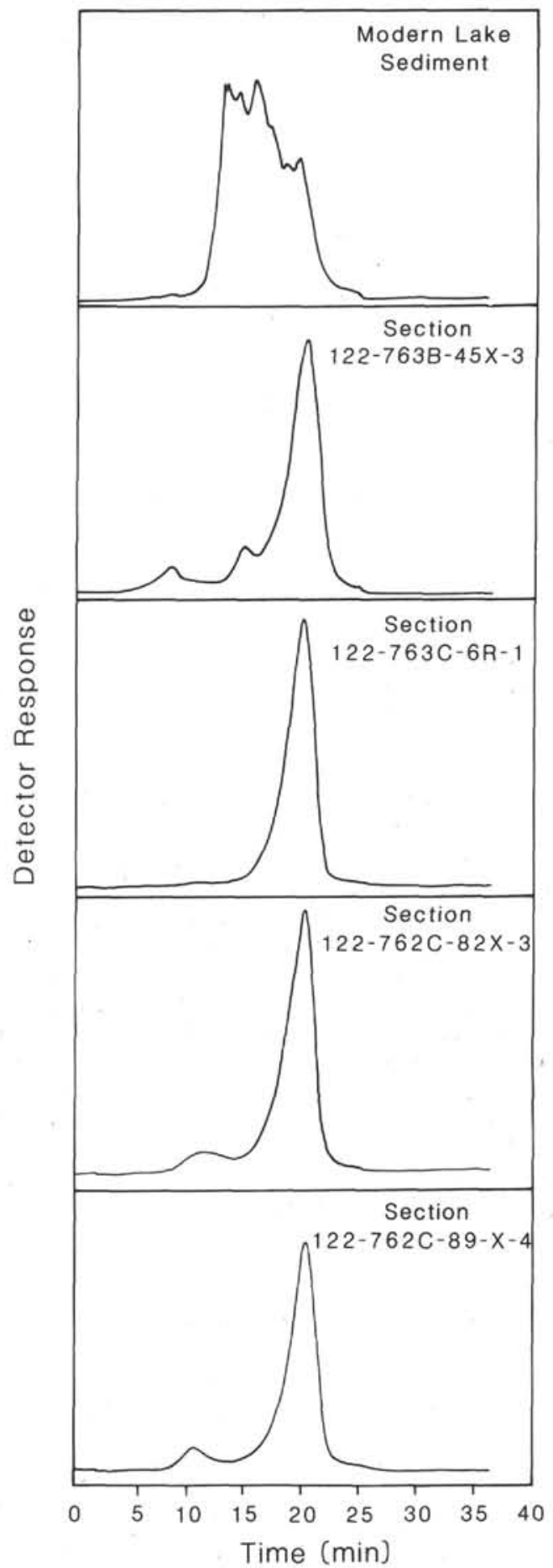

Figure 3. Temperature-programmed Pyran I pyrolysis of organic matter from Lower Cretaceous samples from Sites 762 and 763 and from modern lake sediment. Samples were heated from $30^{\circ}$ to $600^{\circ} \mathrm{C}$ at $30^{\circ} \mathrm{C} / \mathrm{min}$. Volatiles were measured with a flame ionization detector; the detector response is shown as heating progressed. The higher temperatures needed to generate volatiles from the organic matter in the Exmouth Plateau samples suggests that the average molecular weight is higher in the kerogen of these samples than in the sediment from Coburn Pond, Maine. 
Table 4. Ratios of selected Pyran pyrolysis products from sediment samples.

\begin{tabular}{|c|c|c|c|c|c|}
\hline Sample and description & $\begin{array}{l}\text { Depth } \\
\text { (mbsf) }\end{array}$ & $\frac{\text { Benzene }}{\text { Thiophene }}$ & $\frac{\text { Naphthalene }}{\text { Benzothiophene }}$ & $\frac{\text { Phenanthrene }}{\text { Anthracene }}$ & $\frac{\text { Fluoranthene }}{\text { Pyrene }}$ \\
\hline $\begin{array}{l}\text { Modern lake sediment } \\
\text { Coburn Pond, Maine }\end{array}$ & 0.03 & * & * & 1.86 & 0.69 \\
\hline $\begin{array}{l}\text { 122-763B- } 45 \mathrm{X}-3,140-150 \mathrm{~cm} \\
\text { Aptian black silty claystone } \\
\text { (Muderong Formation equivalent) }\end{array}$ & 602.9 & 1.86 & 1.67 & 2.00 & 0.89 \\
\hline $\begin{array}{l}\text { 122-763C-6R-1, } 140-150 \mathrm{~cm} \\
\text { Valanginian dark gray silty claystone } \\
\text { (Barrow Group B equivalent) }\end{array}$ & 662.0 & 2.68 & 2.86 & 1.96 & 1.00 \\
\hline $\begin{array}{l}122-762 \mathrm{C}-82 \mathrm{X}-3,140-150 \mathrm{~cm} \\
\text { Valanginian dark gray silty claystone } \\
\text { (Barrow Group B equivalent) }\end{array}$ & 857.9 & 2.81 & 2.90 & 3.71 & 1.53 \\
\hline $\begin{array}{l}\text { 122-762C-89X-4, } 140-150 \mathrm{~cm} \\
\text { Valanginian dark gray silty claystone } \\
\text { (Barrow Group B equivalent) }\end{array}$ & 926.5 & 6.07 & 8.79 & 4.33 & 1.44 \\
\hline
\end{tabular}

Notes: Pyrolysis was done from $330^{\circ}$ to $600^{\circ} \mathrm{C}$. Products were separated by gas chromatography from $-35^{\circ}$ to $315^{\circ} \mathrm{C}$ on a $30-\mathrm{m}$ DB-5 capillary column before mass spectrometry. ${ }^{*}=$ no thiophene or benzothiophene detected.

These results are consistent with the biomarker, Rock-Eval, and isotopic data in indicating that most of the organic matter in these Mesozoic samples is derived from land plants.

Ratios of selected pyrolysis products reveal progressive changes as sediment age increases (Table 4). These changes may result from diagenetic changes in kerogen compositions with increasing time or thermal maturation, but all other measures indicate that thermal maturity is low. The changes in pyrolysate ratios may instead result from greater proportions of recycled continental organic matter in the deeper parts of the sedimentary sequence on this margin. Comparison of the Exmouth Plateau sample compositions with the pyrolysis products of the modern lake sediment show that the marine sediments contain more sulfur-containing organic compounds than do the freshwater sediments, even though land plants evidently were the principal sources of organic matter to both types of depositional settings. Formation of organosulfur compounds must occur as a result of diagenesis under conditions in which sulfur is available, as in marine sediments.

\section{SUMMARY AND CONCLUSIONS}

Detailed shore-based analyses of extracts of five Lower Cretaceous samples from the Exmouth Plateau equivalents of the Muderong Formation and Barrow Formation Groups B and $C$ have shown that the hydrocarbon source signatures are terrigenous and consistent with a Rock-Eval type III organicmatter-source character. Shipboard chromatographic analyses of the same samples, reported in site summary chapters in Haq, von Rad, O'Connell, et al. (1990), contained a systematic discrimination against high molecular-weight hydrocarbons. A discrepancy, which has now been resolved, existed between hydrocarbon biomarker and Rock-Eval source identifications. Organic carbon isotope ratios and pyrolysis data confirm the predominantly detrital, land-derived nature of the organic matter in these distal Barrow Delta sediments. Biomarker and Rock-Eval data indicate that the organic matter in these Aptian and Neocomian rocks has low thermal maturity. Pyrolysate compositions and hopane isomerization suggest that older sediment layers contain larger proportions of recycled organic matter than is present in younger parts of this sequence, suggesting that the provenance of continental organic matter changed during the accumulation of this Mesozoic deposit.

\section{ACKNOWLEDGMENTS}

Our manuscript was improved by comments from Jurgen Rullkötter. We thank Sneh Achal, Marg Northcott, and Ron Fanjoy of the geochemistry research laboratory of the Geological Survey of Canada, Calgary, for their analytical assistance. PAM and LRS are grateful for the experience (which they actually enjoyed!) of being at sea for 9 weeks during Leg 122.

\section{REFERENCES}

Barber, P. M., 1982. Palaeotectonic evolution and hydrocarbon genesis of the central Exmouth Plateau. APEA J., 22:131-144.

Campbell, I. R., Tait, A. M., Reiser, R. F., 1984. Barrow Island oil field, revisited. APEA J., 24:289-298.

Cook, A. C., Smyth, M., and Vos, R. G., 1985. Source potential of Upper Triassic fluvio-deltaic systems of the Exmouth Plateau. APEA J., 25:204-215.

Espitalié, J., Laporte, J. L., Leplat, P., Madec, M., Marquis, F., Paulet, J., and Boutefeu, A., 1977. Méthode rapide de caractérisation des roches mères, de leur potentiel pétrolier et de leur degrée d'évolution. Rev. Inst. Fr. Pet., 32:23-42.

Exon, N. F., von Rad, U., and von Stackelberg, U., 1982. The geological development of the passive margins of the Exmouth Plateau off northwest Australia. Mar. Geol., 47:131-152.

Haq, B. U., von Rad, U., O'Connell, S., et al., 1990. Proc. ODP, Init. Repts., 122: College Station, TX (Ocean Drilling Program).

Müller, G., and Gastner, M., 1971. The "Karbonat-bombe:" a simple device for determination of the carbonate content in sediments, soils and other materials. Neues. Jahrb. Mineral. Monatsh., 10:466-469.

Risatti, J. B., Rowland, S. J., Yon, D. A., and Maxwell, J. R., 1984. Stereochemical studies of acyclic isoprenoids-XII. Lipids of methanogenic bacteria and possible contributions to sediments. Org. Geochem., 6:93-104.

von Breymann, M., and Berner, U., 1990. Diagenetic dolomite formation in the Sulu and Celebes seas from continentally derived turbidite deposits rich in organic matter. Eos, 71:1392. (Abstract)

Date of initial receipt: 4 June 1990

Date of acceptance: 13 March 1991

Ms 122B-130 